\title{
CLOUD LINEAMENTS - INDICATORS OF FAULT ZONES OF THE EARTH
}

\begin{abstract}
N.N. Shatalov
State institution "Scientific Center for Aerospace Earth Research of Institute of Geological Sciences of National Academy of Sciences of Ukraine", Kyiv, Ukraine, E-mail: shatalov@casre.kiev.ua

Doctor of geological sciences, leading researcher.

The results of investigation of the cloud lineaments interrelation with the activated zones of deep faults of the Earth by aerospace data are presented. It is emphasized that remote methods of research allow studying the interrelation of various geodynamic, hydrodynamic, tectonic, geophysical and other processes occurring in the lithosphere, hydrosphere and air envelope of our planet in specific parts of the Earth. It is noted that the existing litho-hydro-atmospheric relationships are determined by the geodynamics of the endogenous parts of our planet and the constantly changing energy states of the system "space - atmosphere - hydrosphere - lithosphere - the core of the Earth". They are the main driving factors of the earth's geodynamics, which cause the jet migration of energy, gases, heat, radiation and fluids from the deep shells of the planet to the atmosphere, where cloud "autographs" of earth deep faults are formed.
\end{abstract}

Key words: tectonics; geodynamics; faults; cloud lineaments; litho-hydro-atmospheric connections; jet energy.

\section{ХMAPHI АIHЕАМЕНТИ - IHАИКАТОРИ РОЗАОМНИХ ЗОН ЗЕМАI}

\section{М.М. Шаталов}

Державна установа «Науковий иентр аерокосмічних досліджень Землі Інституту геологічних наук НАН Украӥни», Київ, Україна, E-mail: shatalov@casre.kiev.ua

Доктор геологічних наук, провідний науковий співробітник.

Наведено результати дослідження взаємозв'язку хмарних лінеаментів з активізованими зонами глибинних розломів Землі за аерокосмічними даними. Підкреслено, що дистанційні методи дослідження дозволяють в конкретних частинах Землі вивчити взаємозв'язок різних геодинамічних, гідродинамічних, тектонічних, геофізичних та інших процесів, що протікають в літосфері, гідросфері і повітряній оболонці нашої планети. Відмічено, що існуючі літо-гідро-атмосферні зв'язки визначаються геодинамікою ендогенних частин планети і постійно змінюються енергетичними станами системи «космос - атмосфера - гідросфера - літосфера ядро Землі». Саме вони є головними рушійними факторами геодинаміки Землі, що зумовлюють струминну міграцію енергії, газів, тепла, радіації і флюїдів з глибинних оболонок планети в атмосферу, де і формуються хмарні «автографи» земних глибинних розломів.

Ключові слова: тектоніка; геодинаміка; розломи; хмарні лінеаменти; літо-гідро-атмосферні зв'язки; струминна енергія.

\section{ОБААЧНЫЕ АИНЕАМЕНТЫ - ИНАИКАТОРЫ РАЗАОМНЫХ ЗОН ЗЕМАИ}

\section{Н.Н. Шаталов}

Государственное учреждение «Научный изентр аэрокосмических исследований Земли Института геологических наук НАН Украиныл, Киев, Украина, E-mail: shatalov@casre.kiev.ua Доктор геологических наук, ведущчий научный сотрудник.

Представлены результаты исследования взаимосвязи облачных линеаментов с активизированными зонами глубинных разломов Земли по аэрокосмическим данным. Подчеркнуто, что дистанционные методы исследования позволяют в конкретных частях Земли изучить взаимосвязь различных геодинамических, гидродинамических, тектонических, геофизических и других процессов, протекающих в литосфере, гидросфере и воздушной оболочке нашей планеты. Отмечено, что существующие лито-гидро-атмосферные связи

(c) N.N. Shatalov, 2019 
определяются геодинамикой эндогенных частей планеты и постоянно изменяющимися энергетическими состояниями системы «космос - атмосфера - гидросфера - литосфера - ядро Земли».Именно они являются главными движущими факторами геодинамики Земли, обуславливающими струйную миграцию энергии, газов, тепла, радиации и флюидов из глубинных оболочек планеты в атмосферу, где и формируются облачные «автографы» земных глубинных разломов.

Ключевые слова: тектоника; геодинамика; разломы; облачные линеаменты; лито-гидро-атмосферные связи; струйная энергия.

\section{Introduction}

It would seem that there may be common between the deep fault zones of our planet and the clouds, rapidly moving along the earth's surface. In fact, until the end of the 19th century, meteorologists and environmental scientists were believed that atmospheric clouds did not have clear linear boundaries. However, at the beginning of the twentieth century, the outstanding Russian geologists I.V. Mushketov, D.I. Musketov and the French geologist A. Schlumberger expressed a different point of view. In particular, while working in Central Asia, the father and son Mushketov discovered that cloudy ridges arise on the crustal faults that are not blown away by air currents [Мушкетов, Мушкетов, 1935]. During the field studies of the Alpine mountain region, A. Schlumberger, using only visual observations, also pointed to the possible connection of clouds of meteorological nature with faults. At the same time, the problem raised more than 100 years ago in their writings did not receive further development. This idea was then debatable, since it relied only on field visual observations.

\section{Results and their discussion}

Reliable data on the relationship of clouds with faults were obtained only at the beginning of the space age. In numerous space images, an amazing "cloud" phenomenon was discovered - linearly extended chains and ridges of clouds with clear geometric boundaries. Over the next 50 years, after the launches of spacecrafts, a wealth of factual material was accumulated on this issue. It is not surprising that the linearly extended ridges of clouds of meteorological nature, found in satellite images, aroused great interest in this phenomenon in the scientific community of several countries. After the chains and ridges of clouds revealed in the photographs were compared with maps of deep faults in the earth's crust, it became clear that cloud lineaments are associated with the geological structure, geodynamics, and tectonics, namely, with large discontinuous disturbances in the lithosphere of our planet. Therefore, thanks to remote research methods, the urgent problem of hydro-lithic and atmospheric connections and phenomena attracted increased attention of researchers both in the countries of the former USSR and abroad [Бондур и др., 2016; Воробйов та ін., 2016; Морозова,1980, 1993, 1996; Shou, 2006].

Thus, by the beginning of the 21 st century, at the intersection of three sciences - the geology, oceanology and meteorology, a new scientific direction had actually emerged, studying the interconnection of various geodynamic, hydrodynamic, tectonic, geophysical and other processes taking place in the lithosphere, hydrosphere and air shell of our planet.

In this article, based on an analysis of the large volume of satellite images of recent years, the author provides information on cloud lineaments and "living" deep fault zones of the Earth - peculiar "transfers" where modern processes in the planet's geospheres - lithosphere, hydrosphere and cloud layer of the atmosphere are fast and bright.

In the last five decades, when analyzing images of the Earth from space, it was suddenly discovered that deep faults and other large tectonic structures (platforms, plates, megablocks, mountain systems, etc.) actively influence the formation, structure and pattern of the Earth's cloud atmosphere. On the other hand, analyzing satellite images and revealing the characteristic cloud connections with faults, one can judge online the deep structure of the lithosphere and modern geodynamic, hydrodynamic, tectonic, geochemical and other processes taking place there. Undoubtedly, these data are also important in the study of the surface parts of the planet, in particular the hydrogeological and landscape-geomorphological features of the earth's crust and the processes occurring here. These relationships can also be used to study the processes of heat and mass transfer [Лялько, 1985] of the patterns of the distribution of oil, gas and gas-liquid fluids, ore-bearing structural tectonic zones, knots, fields, and specific deposits of solid minerals. Such observations should also be used in the construction of buildings and structures, power lines, gas and oil pipelines, and other ground and underground economic facilities. 
In our opinion, the communications observed between remote clouds and deep faults of the Earth, which are observed by remote sensing methods, oblige geologists, volcanologists and seismologists to use them to identify currently geodynamically active "living" faults in the lithosphere, i.e. and related modern seismotectonic, volcanic, landslide and many other catastrophic geological processes. In addition, meteorologists constantly need to keep in mind that deep faults and individual large tectonic segments of the lithosphere often clearly determine individual anomalies in cloudy fields of the atmosphere.

In a detailed analysis of images of the Earth from space, the author of the article in energetically active parts of the planet managed to find a close relationship between the deep faults of the Earth and the linear elements of the cloud cover - "cloud lineaments". In this case, clouds act as phenomenal indicators, or "autographs" of deep faults, their spatial orientation and structure. In fact, cloud lineaments "trace" large, currently activated heterogeneities in the lithosphere. As you know, cloud fields are usually located at different heights from the earth's surface - from 1 to 20 $\mathrm{km}$. These fields, undoubtedly, are peculiar indicators of the dynamics of processes in the atmosphere and lithosphere. However, it is obvious that, by their location, the chains of clouds, or gaps (cloudy canyons) among them indicate only specific deep faults, fault systems or their fragments that are geodynamically active only at the present time, namely during the Earth's survey from space. Since the time of the Earth's imaging by the space vehicles is often recorded with accuracy to days, minutes and seconds, the obtained materials allow us to track geodynamicallyactive in space and time, i.e. "living" deep faults of our planet. Such "space monitoring", in our opinion, is important because the Earth's deep faults are long-lived (many millions of years) tectonic structures and movements along them either fade out or become more active. Thus, in the future, when the amount of information from outer space will increase significantly, it will be possible to monitor online "living" deep faults and predict the catastrophic natural processes in the various regions of the planet - volcanic eruptions, earthquakes, tsunamis, landslides, mudflows, submergence, flooding, tornadoes, etc.

In connection with a change in the Earth's rotation regime and constantly changing conditions of tectonics, geodynamics, heat and mass transfer in the lithosphere, hydrosphere and atmosphere of our planet, in our opinion, there are three main types of cloudiness connection with deep faults, namely:

1 - linear chains, ridges and stripes of clouds against the background of cloudless space are concentrated and oriented along the strike of deep fault zones or their fragments (Fig. 1-3);

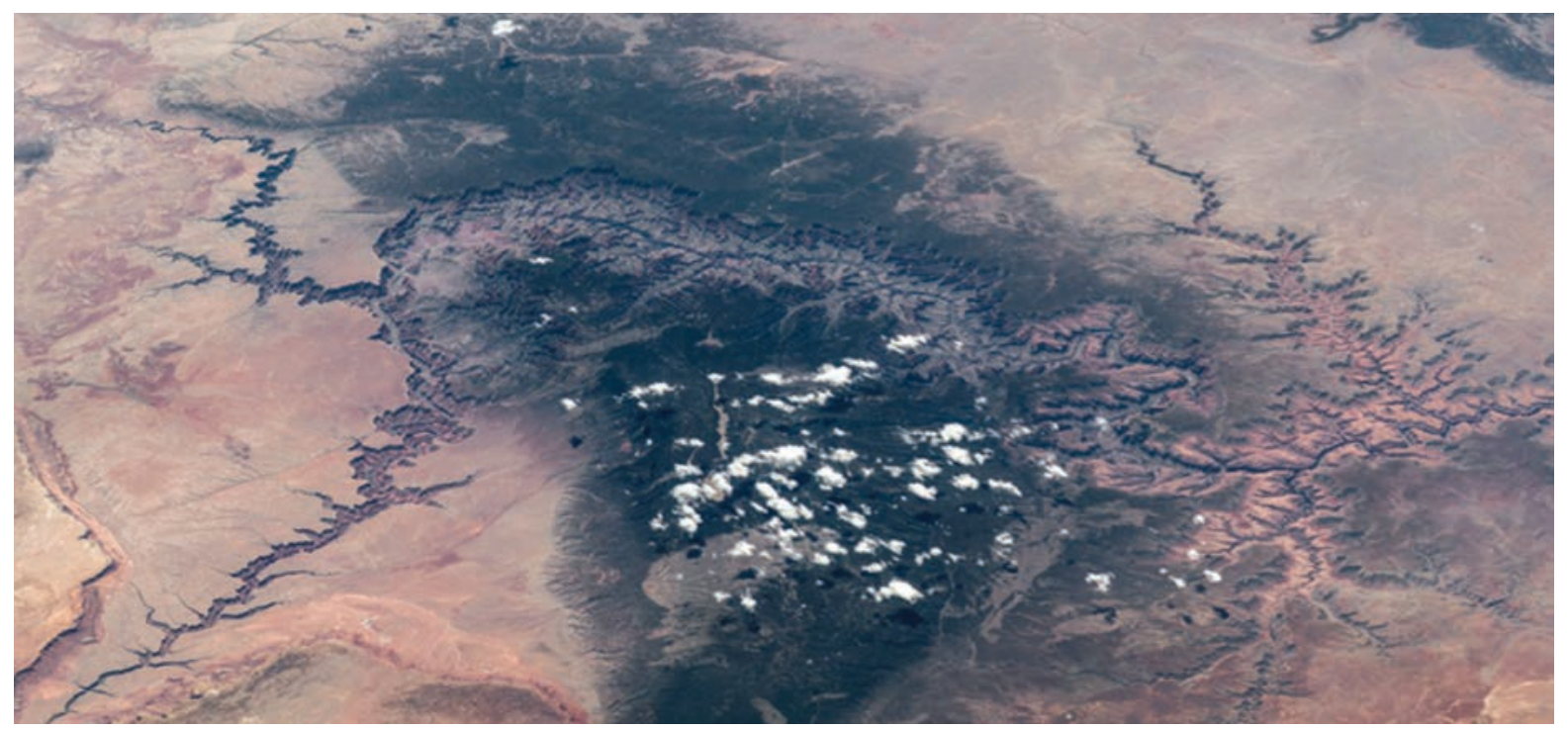

Fig. 1. Linear cloud chains over activated large faults in the Arizona desert, USA. By the location of the clouds, it can be judged that at the time of the survey, a large structural node for crossing the faults was activated here. The image was taken from the international space station, from an altitude of $400 \mathrm{~km}$ from the Italian surveillance module "Dome"(2016). Photo: Jeff Williams, NASA. https://www.instagram.com/astro_jeffw/?hl=en

Рис. 1. Лінійні хмарні ланцюги над активними великими розломами в пустелі Арізона, США. За розташуванням хмар можна судити, що на момент зйомки тут був активований великий структурний вузол для перетину розломів. Знімок зроблено з міжнародної космічної станції італійського модуля спостереження «Купол», з висоти 400 км (2016). Фото: ДжефФ Вільямс, NASA. https://www.instagram.com/astro jeffw/?hl=uk 


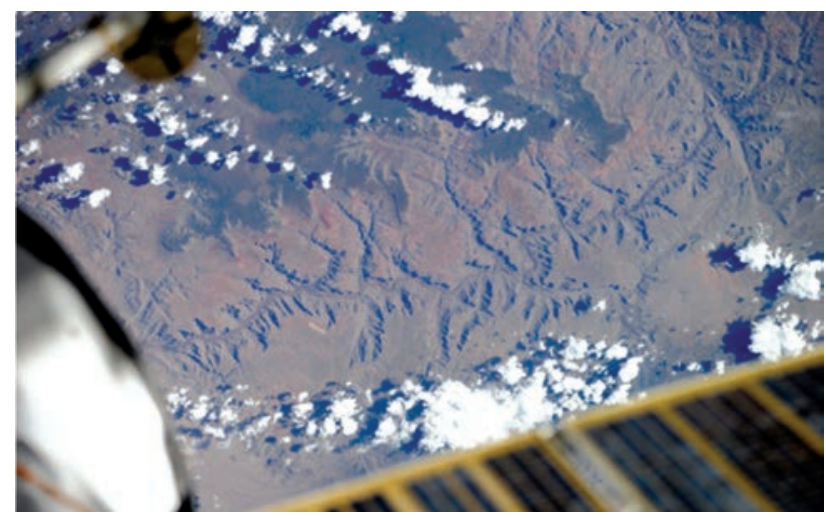

Fig. 2. A cascade of cloud lineaments over geodynamically active ignored fault zones in the platform part of the US Arizona desert. In the upper left corner of the image there are faults of the north-western orientation, and in the lower part of the image there are faults of the north-east and southeast directions. Photo ROSKOSMOS: https://www.roscosmos.ru/366/

Рис. 2. Каскад хмарних лінеаментів над геодинамічно активними ігнорованими зонами розломів у платформній частині пустелі Арізони США. У верхньому лівому куті зображення розломи північно-західного напрямку, а в нижній частині зображення - розломи північно-східного та південно-східного напрямків. Фото ROSKOSMOS: https://www.roscosmos.ru/366/

2 - over some deep faults, on the contrary, the bands of cloudless "dark canyons" are formed in cloudy fields, as if the "translucence" ("dispersion") of fault tectonic zones in the cloud cover occurs;

3 - deep faults serve as a sharp boundary of the distribution of cloud fields or the boundary of a change in cloud forms, i.e. there are sharp linear boundaries of cloudy and cloudless massifs.

The tectonic-geodynamic, geophysical, and geochemical reasons for the occurrence of precisely such links of deep faults with clouds have not yet been fully elucidated. This indicates the complexity of the problem and the variety of ways to solve it. However, it is obvious that the formation of cloud fields in general and linear elements of the cloud cover over the fault zones in particular is predetermined by the total and very complex effect of many heat, mass and energy processes occurring in the system "space -atmosphere - hydrosphere lithosphere-Earth's core".

In this paper, we restrict ourselves to characterizing the general laws of litho-hydro-atmospheric interactions. The main ones are:

1 - linear elements of cloud cover in satellite images stand out above all activated ones, i.e. "living" deep fault zones (or their fragments) of the orthogonal (along meridians and latitudes) and diag-

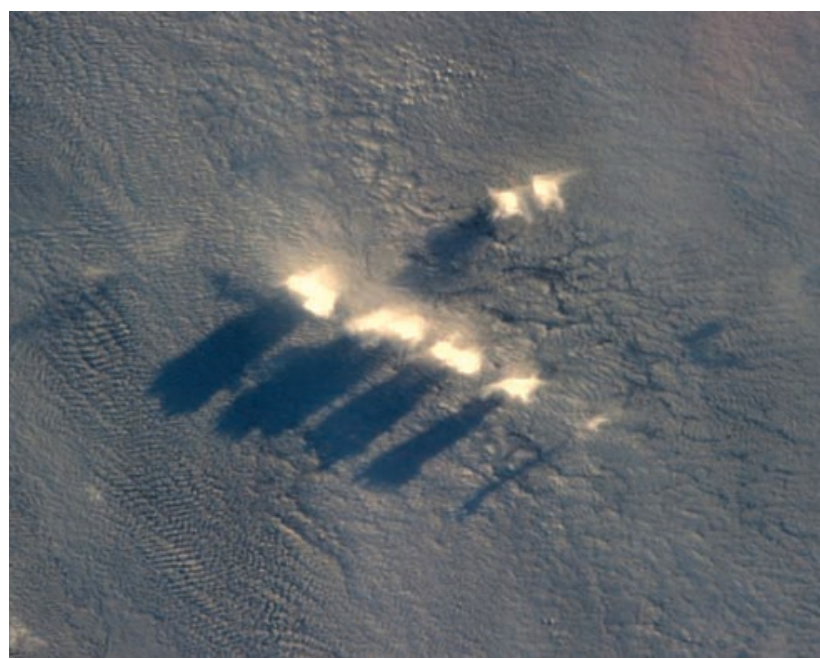

Fig. 3. A chain of clouds and their shadows over the "revived" fault. Photo from the ISS 09/27/2014 Astronaut Gerst noted: "Even clouds sometimes like to stand out". Photo: Alexander Gerst / ESA / NASA. https://alexandergerst.esa.int/

Рис. 3. Ланцюг хмар та їх тіні над «відродженим» розломом. Фото з МКС 27.09.2014. Астронавт О. Герст зазначив: «Навіть хмари іноді люблять виділятися». Фото: Олександр Герст / ESA / NASA. https://alexandergerst.esa.int/

onal (northwest and northeast) systems of the planet [Бондарчук, 1961; Чебаненко, 1977]. The cloud lineament systems in this case correspond to the planetary fracture network of the Earth.

2 - being a reflection of deep heterogeneities, i.e. derivatives of the Earth's modern geodynamics, the cloud lineaments are observed both over very ancient, Precambrian and relatively young deep faults, regardless of where they are mapped - within the land, sea or ocean. Therefore, if such a geodynamically active, i.e. the "living" deep fault extends on the land, and then is traced at the depths of the sea or ocean, then the linear elements of the cloud cover will trace it both over the land and over the sea (Fig. 4-6).

3 - most often, the cloud lineaments appear over the activated deep faults (or fragments of them) of a planetary rank, delimiting the most important tectonic segments of the lithosphere of our planet, for example, the ancient Precambrian platform structures from the younger platforms, the ancient and young platforms from folded and uneven-aged mountain structures, etc. The cloud lineaments often trace intra-platform faults that separate large (with different structures) megablocks and geoblocks from each other, the ancient Precambrian platforms from younger mountain systems, etc. Undoubtedly, 

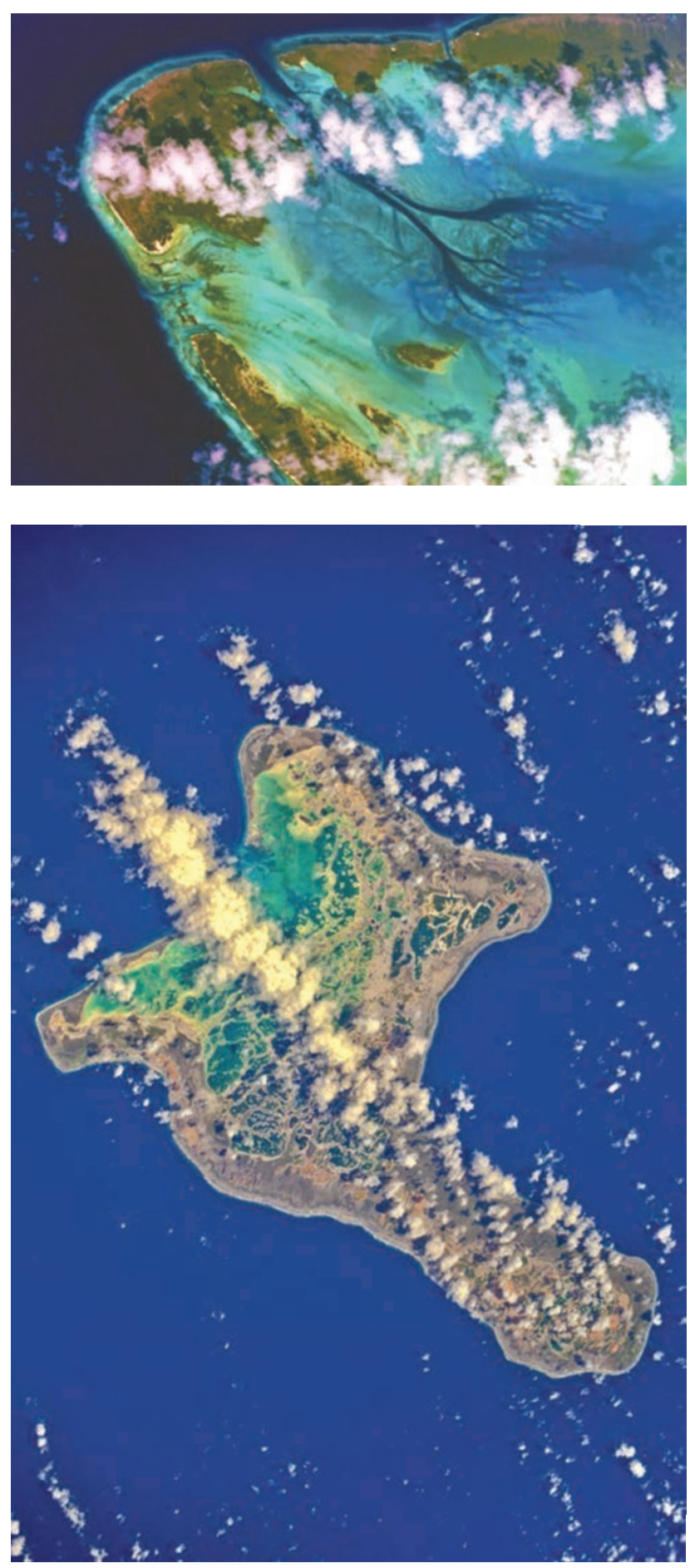

Fig. 5. Subparallel chains of clouds above the "living" faults of the land and the sea. Christmas Island (Kiribati). The largest atoll in the world with an area of $21 \mathrm{~km}^{2}$. Altitude $13 \mathrm{~m}$. The photo was taken at the end of 2017 from the ISS. Photo by Sergey Ryazansky. https://fishki.net/-ostrov-rozhdestva-kiribati-photo.htm

Рис. 5. Субпаралельні ланцюги хмар над «живими» розломами суші та моря. Острів Різдва (Кірібаті). Найбільший атол у світі з площею 21 км². Висота - 13 м. Фото зроблено наприкінці 2017 року з МКС. Фото Сергія Рязанського. https://fishki.net/-ostrov-rozhdestvakiribati-photo.htm
Fig. 4. Chains of clouds over activated faults. Aldabra Island (Seychelles) isan atollin the Indian Ocean. Atthe base of the second largest atoll in the world is the crater of an extinct volcano. Photo published 24.10. 2017. It was made from the international space station from the Italian observation module "Dome" from an altitude of $400 \mathrm{~km}$. Photo: cosmonaut Sergeiy Ryazansky. http://sergey-ryazanskiy.ru/interviews/

Рис. 4. Ланцюги хмар над активними розломами. Острів Альдабра (Сейшельські острови) - атол в Індійському океані. В основі другого за величиною атола у світі - кратер згаслого вулкана. Фото опубліковано 24.10.2017. Знімок зроблений з міжнародної космічної станції італійського модуля спостереження «Купол» 3 висоти 400 км. Фото: космонавт Сергій Рязанський. http://sergey-ryazanskiy.ru/interviews/

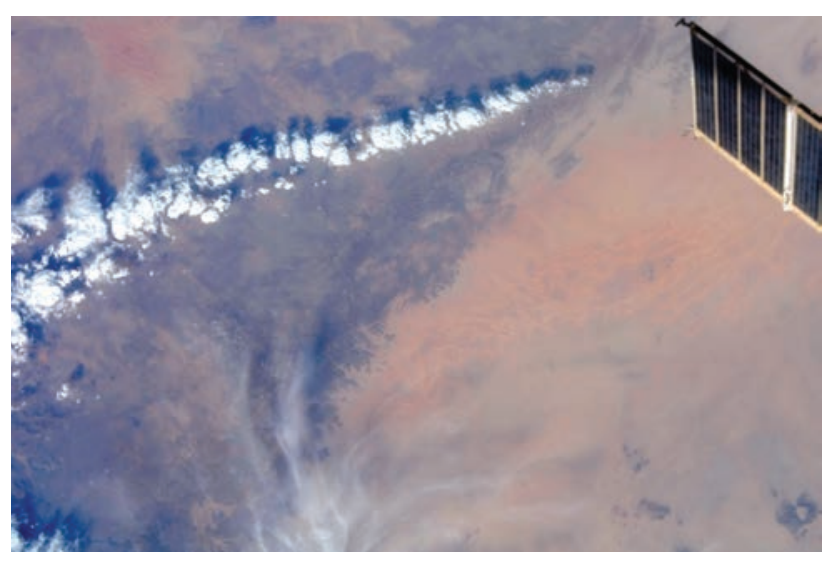

Fig. 6. "Live" fault of the platform part of the African continent, recorded by a powerful cloud lineament. Photo: ROSKOSMOS. https://www.roscosmos.ru/366/

Рис. 6. «Живий» розлом платформної частини африканського континенту, зафіксований потужним хмарним лінеаментом. Фото: ROSKOSMOS. RUhttps://www.roscosmos.ru/366/

the clouds also "trace" the deep faults along which the largest (thousands of kilometers long and hundreds - wide) crevices in the lithosphere of the planet - aulacogens, paleorifts, rifts - formed. Cloud lineaments also trace long-lived, tectonically active deep fault zones of a planetary rank. They are called "through", because they are simultaneously dissecting ancient and young platforms, aulacogens and rifts of different ages, foothill troughs and young mountain structures. At the same time, it was established that through the deep faults on the earth's surface are often expressed indistinctly and fragmentarily, i.e. have a hidden, as if veiled character.

4 - thickening zones of cloud lineaments, which are interpreted on the satellite images of a high level of generalization, are most often observed not over the ancient platforms, but over younger, energy-active mountain constructions of our planet: 
the Andes and Cordillera in America; the Alps, Carpathians, Crimea, the Caucasus in Europe; the Himalayas, Pamir, Tien Shan, Hindu Kush and many others in Asia (Fig. 7). This indicates that the energy supply of the impact of the lithosphere on the atmosphere and hydrosphere is mostly young, i.e. in alpine mountain regions is incomparably higher than on ancient platforms. It is also known that in the alpine mountain-folded regions of the planet, significant areal heterogeneities of the mantle and lithosphere, numerous and differently oriented deep faults, as well as fault systems and geodynamically active nodes of their intersection are observed. A huge amount of electromagnetic, radioactive and other "jet" energy is emitted from the bowels of the Earth into the hydro-, litho-, and atmosphere constantly (and periodically very intensively) through deep faults, and significant heat and mass transfer processes occur between the lithosphere, hydrosphere, and atmosphere. In this regard, in the predominantly "growing" upland regions, in- tense earthquakes, volcanic eruptions, landslide, mudflow, karst and many other catastrophic geological processes are occurring.

5 - the length of cloud lineaments in the atmosphere usually reaches hundreds, sometimes thousands of kilometers, and the width is up to the first tens of kilometers. Cloud anomalies in the atmosphere are recorded at altitudes from 1 to $20 \mathrm{~km}$. The discovery of cloudy "autographs" of deep-seated earth faults at high altitudes undoubtedly indicates a significant influence of deep tectonics and geodynamics on the atmosphere of planet Earth. It is also obvious that the clouds, with changing geodynamic and energy conditions in the tectonosphere of the planet, move fairly quickly both relative to deep faults and relative to the earth's surface as a whole. Consequently, their cloudy "autographs" previously formed over deep faults in this case quickly disappear. In some cases, on the same satellite image above different faults or different fragments of the same fault, there are ridges and canyons. Conse-

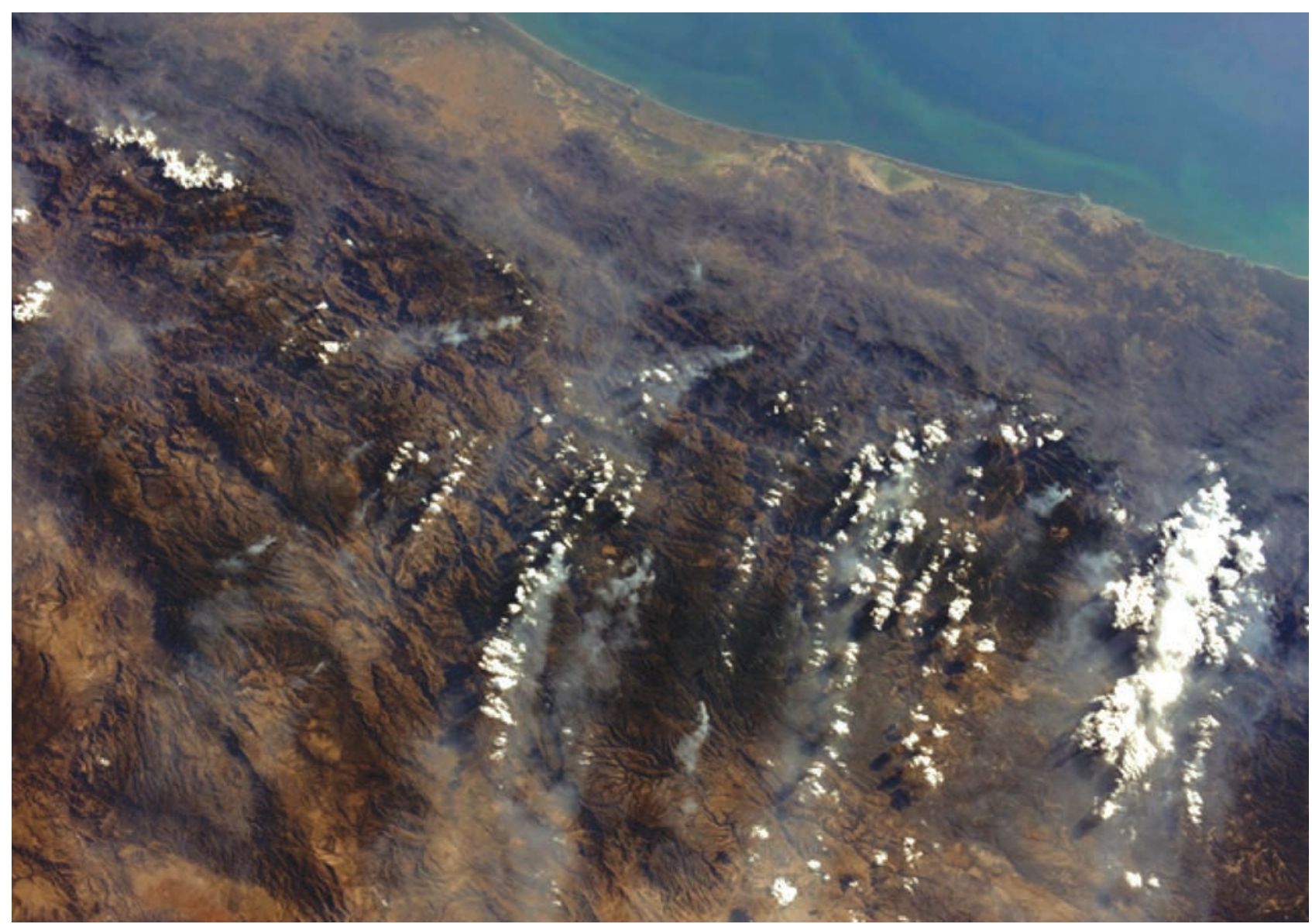

Fig. 7. Cloud chains over numerous geodynamically active fault zones in the mountain-folded region of our planet. Photo: ROSKOSMOS. https://www.roscosmos.ru/366/

Рис. 7. Хмарні ланцюги над численними геодинамічно активними зонами розломів у гірському регіоні нашої планети. Фото: ROSKOSMOS. https://www.roscosmos.ru/366/ 
quently, the geodynamic activity of the lithosphere of our planet can lead to both generation and degradation of clouds, depending on the energy state of the earth's crust and atmosphere.

Researchers have not yet unanimously agreed on possible geodynamic, physicochemical, and other causal relationships of cloud lineaments with deep faults of the Earth. The physical principles of this phenomenon to date have also not been unequivocally explained, although the problem has existed for more than 50 years. In our opinion, the reason for the occurrence of cloud ridges and single lineaments above deep faults may be increased the concentrations of positively or negatively charged metallized fluids, water aerosols and gases - oxygen, helium, hydrogen, nitrogen, radon, methane, etc. in the surface layer of the atmosphere. Since in the satellite images above different faults or fragments of the same fault, cloud ridges and canyons are observed, it should be concluded that in these faults an alternating geophysical character of the anomalies or high concentrations of the fluids and aerosols, positively or negatively charged is observed. The sharp linear boundaries of dispersion of the cloudiness (i.e., the formation of canyons in cloudiness fields) can be due to intense vertical gasjet-fluid energy rising from the bowels of the Earth along the deep faults of the lithosphere [Шестопалов и др., 2018].

However, it is obvious that the satellite monitoring of the various dynamic processes occurring in the lithosphere, hydrosphere and atmosphere of our planet is very relevant. In particular, the Earth's remote sensing materials quite accurately determine the basic parameters of the atmosphere, which allows one to get an adequate representation of global and regional changes in the lithosphere-hydrosphere-atmosphere system at the various spatial and temporal scales. In this regard, the described exclusive phenomenon in space geology has attracted the great attention of the specialists in the various fields - tectonists, geologists, geographers, seismologists, etc. After all, on the Earth's images from space, the contours of the clouds were sufficiently pronounced to map the activated deep faults using photos from space and structural nodes of their intersection within the platforms, marine areas and shelf zones of the continents. Although the physicochemical nature of the unusual and exclusive phenomenon has not been reliably clear, the accumulated information can still be used in practice primarily for revealing the geodynamic activity of the seismically active regions [Морозова, 1996; Бондур и др., 2016; Воробйов та ін., 2016].

It was only thanks to remote sensing of the Earth that it became clear that the length of linear cloud lineaments can reach several hundred and even thousands of kilometers. The satellite imaging also revealed another natural phenomenon, comparable to the first in importance, but opposite in nature: the dispersion of the clouds above the fault [Морозова, 1980]. At the same time, cloud dispersion can manifest itself in two ways: either in the form of a narrow gap (canyon) arising in a continuous cloud cover, or through the formation of a sharp fixed linear boundary of a cloud array thrusting over a fault. All three types of unusual clouds received a common name - linear cloud anomalies. On the other hand, it is obvious that this phenomenon cannot be caused solely by atmospheric processes, since linear cloud anomalies are tied to the deep tectonic elements of the planet, i.e. are their projection and repeat the configuration of the faults of the earth's crust. On the other hand, the geologists are well aware that a great many faults exist in the depths of the Earth and on its surface. At the same time, only a few of them are displayed in the cloudy fields: cloud lineaments periodically appearing and disappearing, they "live" for several minutes or hours, and sometimes even more than a day.

According to the author of the article, the existing litho-hydro-atmospheric relations are determined by the internal geodynamics, i.e. endogenous parts of our planet and constantly changing energy states of the system - "Space - atmosphere - hydrosphere - lithosphere - core of the Earth". Among the main space factors that determine the modern geodynamics of the planet's atmosphere, hydrosphere and lithosphere, we should mention the complex energy (gravitational, magnetic, electromagnetic, etc.) influence on the Earth and its spheres, first of all, of the Galaxies and the Sun, and secondly, of the planets of the Solar system. The interaction of the three shells of our planet - the atmosphere, hydrosphere and lithosphere, is undoubtedly due to cosmocentric and internal (endogenous) geodynamic, geological and geophysical reasons. Many space factors, for example, solar activity, migration of the poles, the changes in the inclination of the Earth's axis, the shape of the Earth's orbit, the rotation rate and curvature of the Earth, actively influence on the planet's geodynamics and energy 
condition, determine the modern activation of the Earth's deep faults and the appearance of extended cloud lineaments. The space factors determine the processes affecting the upper layers of the lithosphere, mantle and core of the Earth. Under the influence of internal physicochemical processes in the Earth's core and mantle, as well as near and far space (resonant space pressure on our planet), the face of the Earth is formed, i.e. landscape shell of the planet and changes in atmospheric circulation take place. The relationship between the geodynamics of the atmosphere, the hydrosphere, and tectonic processes in the lithosphere is due to the action of the same exogenous and endogenous forces of the Earth. The rotational movement of the planet around its axis (rotogenesis of the Earth) also intensively affects the structure and movement of huge masses in the lithosphere and on the circulation in the hydrosphere and atmosphere. Cosmocentric geodynamics leads to the activation of the deep segments of the planet and its faults, i.e. to its modern tectonic and energetic activity.In turn, the activated deep faults are an active release of gases, fluids and other "jet" energy from the bowels of the Earth. It is these processes that have a significant impact on the hydrosphere and atmosphere. In our opinion, only at such moments in the atmosphere do linear cloud lineaments form.

Let us briefly dwell on a number of deep-seated factors of the Earth, to one degree or another affecting the formation and dynamics of cloud lineaments and cloud cover in general:

1. GAS RESPIRATION OF THE EARTH. Our planet Earth is an open and self-organizing geodynamic system, formed mainly due to deep processes caused by the action of sources inside the Earth, among which deep gases occupy a leading place. From the Earth's core, under the influence of gigantic pressure, a powerful stream of gases constantly penetrates to the surface of our planet, penetrating through all the Earth's shells, the hydrosphere of the atmosphere and further into space. Consequently, from the compressed core, from the Earth's mantle and lithosphere, into the hydro- and atmosphere through the faults come natural deep gases - oxygen, nitrogen, hydrogen, helium, methane, hydrogen sulfide, carbon dioxide and many others. In the scientific literature, this global process of planet self-organization was first described under the name "gas breath of the Earth" [Вернадский, 2005]. So, at the moments of geodynamic activation of various regions of the planet, jet gas emanations are thrown into the hydrosphere and atmosphere of the Earth through the deep faults and feathering them the tectonic fractures. To date, it has been established that these jets not only propagate in the hydrosphere, upper parts of the lithosphere and lower layers of the atmosphere, but also penetrate to the great heights - into the troposphere and ionosphere. Consequently, tectonic activations in the Earth's lithosphere lead to intensive accumulation of products of the "gas breath of the Earth" in the hydrosphere and atmosphere, but their role with respect to the formation or dispersal of clouds is not yet understood. In our opinion, everything is determined by the composition of the gases ejected from the depths of the Earth, the temperature conditions of the atmosphere, photochemical processes and gas reactions. Among the deep gases, nitrogen, oxygen and hydrogen play a major role. The earth's crust, for example, is essentially an oxygen shell, in which oxygen is mostly included in the structure of rocks and minerals. If following V.I. Vernadsky one assumes that the hydride core is located in the center of our planet, and then the transition of hydrides into metals should be accompanied by the abstraction of hydrogen and its migration to the surface of the Earth. An analysis of the evolutionary development of the Earth as the planetary body of the solar system and the galaxy as a whole indicates that, during the degassing of the depths, the atmosphere and hydrosphere gradually formed here. The products of deep degassing are united by geologists under the general name "fluids". Since the existence of aqueous solutions and $\mathrm{H}_{2} \mathrm{O}$ vapor itself is possible only in the uppermost horizons of the lithosphere, in their predominant mass the fluids indicated above are not solutions, but gas mixtures. Consequently, any fluid heat and mass transfer along the section of the earth's crust occurs in substantially gaseous media. Fluid should be understood as essentially an aqueous, water-gas, and vapor medium enclosed or transported in the mass of rocks of the lithosphere along deep faults. The various fluid components in the lithosphere combine with petrogenic and ore elements, and in the atmosphere with oxygen, nitrogen, and other gases.

The mechanism of pulsed degassing and the cyclical development of endogenous processes in the Earth are closely interconnected. Cycling is expressed in the periodic manifestations of volcanism, magmatism, metamorphism, ore formation, and 
fluid regime. A fluid gas-water system is a set of fluid components representing a stationary system with the boundary thermodynamic and physicochemical parameters.

2. RADIOACTIVITY. Our Earth is a generator of other gases, which are the decay products of natural radioactive elements - uranium, thorium, potassium, etc. Uranium and thorium in the process of their decay generate alpha particles, which are nothing but the nuclei of the helium element. Radon, helium and argon-40, being gases of radiogenic origin, make up the most important part of the gas breathing of the Earth. The permeable deep faults are undoubtedly powerful channels through which helium, radon, and other components migrate to the Earth's surface, most often together with fluids circulating in the fault zones. Geologists and geophysicists have found that the atmosphere of our planet is also constantly ionized by X-rays and decay products of radioactive substances [Вернадський, 2005] contained in the rocks of the earth's crust - mainly in granites. X-rays and decay products of radioactive substances create a constant, natural background in the atmosphere. According to the scientists, it accounts for approximately $80 \%$ of the total ionization intensity, i.e. upon irradiation of air with X-rays, alpha and beta particles, the cloud condensation nuclei arise constantly and in the large amount. In cases when the very intense jet emissions of radioactive energy occur from the mantle and lithosphere into the atmosphere and hydrosphere of our planet in the zones of deep faults (at the moment of their activation), extremely high radiation doses are formed in the atmosphere, at which cloud condensation of nuclei increases more than hundreds of times. In our opinion, this is one of the main reasons for the formation of chains and stripes of clouds above the "living" faults.

3. HEAT FLOWS. It is well known that there are relatively constant heat flows from the mantle and lithosphere of the Earth to the hydro- and atmosphere. At the same time, it was found that the intensity of these flows in mountainous areas is several times higher than in ancient platform sites "cratons" [Кутас и др., 1989]. There is also no doubt that the geodynamic processes in the bowels of our planet lead to a decrease or an intensive increase in the thermal "respiration" of the Earth. The source of heat fluxes is the upper mantle, tectonomagmatic processes in the lithosphere and, in part, the radiogenic heat of the earth's crust. According to the specialists in tectonics, geophysicists, and meteorologists, deep thermal radiation from the bowels of the planet leads to heat and mass transfer-convective heat transfer, turbulent mixing, etc. [Лялько, 1985]. Such mutual exchange processes between the lithosphere, hydro- and atmosphere affect the distribution of temperature, pressure (density), humidity, number and composition of cloud condensation nuclei in different layers of the atmosphere. Undoubtedly, the thermal "respiration" of the Earth can cause ascending (in the event of a change in the geodynamics of the planet and activation of tectonic faults) or descending (in the case of their attenuation) movements in the atmosphere, troposphere and ionosphere. In turn, these processes lead to the formation of clouds, their chains over the deep faults or to the degradation and dispersion.

4. ENERGY FLOWS. As you know, the Earth has its own original gravitational electro-magnetic field and additionally receives huge energy from outer space. Consequently, the anomalies of the above geophysical fields are closely related to the deep heterogeneities of the Earth on the one hand, and near and far space on the other. The constant and variable components of atmospheric processes, in turn, clearly respond to the variations in gravitational electromagnetic fields, which leads to an increase or decrease in atmospheric pressure and to a change in heat and mass fluxes both in the lithosphere and in the atmosphere of our planet. During the periods of the intensification of various segments of the lithosphere through deep faults from the bowels of the Earth the intense energy flows pass into the atmosphere and hydrosphere and affect the dynamics of the atmosphere and the formation of clouds. Such streams of jet energy are very often accompanied by a rumble, a roar, electric discharges, crackling, glowing and many other abnormal ones, i.e. very spectacular processes. In addition, the increased fracturing and watering of the lithosphere of the planet greatly contribute to these abnormal processes. It is established that the rocks of the earth's crust in the zones of deep faults are the most fractured and flooded. During the periods of geodynamic activation of the Earth in some of its segments, the fracturing increases, and watering is expressed in the raising the level of groundwater. The higher fracturing, undoubtedly, contributes to the migration of energy flows, emissions of gas and thermal emanations into the atmosphere. The higher watering of deep faults, due to evaporation, leads to 
an increase in the moisture content of air, which, all other things being equal, induces the condensation of water vapor and the formation of clouds.

\section{Conclusions}

So, as a result of the uneven rotation of the Earth around its axis, around the Sun, and together with the Solar system in the Galaxy, and the aforementioned energetic influence of the Space on the Earth, in the core of our planet and its shells (tectonosphere, hydrosphere and atmosphere) the intense geodynamic stresses and energy-heat-mass transfer transformations constantly occur, as a result of which the internal energy of our planet, gases and heat from the depths of the Earth periodically and very intensively "splash out" into the lithosphere, hydrosphere and atmosphere. The most important part of the "gas breathing of the Earth" is oxygen, hydrogen, helium, radon, argon and other isotopes that carry important information about the processes in the core, mantle and tectonosphere of our planet. It is also obvious that the supply channels for the migration of jet energy from the bowels are the orthogonal and diagonal systems (or their fragments) of the Earth's deep faults. The main driving factors of the geodynamics of the Earth, which determine the jet migration of energy, gases, heat, radiation and liquid fluids from the planet's deep shells to litho-, hydro- and the atmosphere, are undoubtedly the mechanical and physico-chemical forms of matter motion, namely constant interaction ("struggle") of the forces of gravitational compression and thermal expansion, as well as the processes of physicochemical transformation of matter - phase, polymorphic, nuclear and others.

The space images presented in the article clearly show linearly extended cloud anomalies that we found within the platform parts, mountain structures, and marine areas of the planet. They are rep-

\section{References}

Bondarchuk V.G. (1961). Basic questions of tektooroheny. Kiev: Isdatelstvo AN USSR, 381 p. (in Russian).

Bondur V.G., Zverev A.T., Gaponova E.V. (2016). Variability of precursors for the lineament systems revealing by satellite images in the periods of the violent earthquakes. Issledovanie Zemliiz kosmosa, No 3, p. 3-12 (in Russian).

Chebanenko I.I. (1977). Theoretical aspects of tectonic divisibility of the earth's crust. Kiev: Naukova Dumka, 83 p. (in Russian). resented by chains or narrow banks of clouds on a background of cloudless space. Linear cloud anomalies recorded by methods of remote sensing of the Earth (ERS) are a consequence of the current stressstrain state of the lithosphere, the geodynamic and energy activity of the core, the Earth's mantle, and deep faults. The tectonic activity in the subsurface parts of the earth's crust and the formation of cloud coverage in the atmosphere, according to the author of the article, is predetermined by the total and very complex effect of many heat-, mass- and energy processes occurring in the system "Space - atmosphere hydrosphere - lithosphere - Earth's core".

Linear cloud anomalies are undoubtedly "autographs" of the activated deep faults or their fragments. They quite accurately determine the geodynamic parameters of faults and give an idea of global and regional changes in the lithosphere-hydrosphere-atmosphere system. The above information on the connection of cloudiness with the "revived" deep faults, in our opinion, clearly and convincingly indicates that over the past half century, our earthly civilization has received important, qualitatively new, comprehensive information about the processes occurring in the litho-hydro- and atmosphere of the Earth. It is important that this information is obtained remotely, i.e. using remote sensing methods. In the near future, remote sensing methods will receive their further development and from various points and heights the earth's shells of the Earth will be constantly illuminated and scanned online. At the same time, observations will be made of the Sun, the planets of the solar system and deep space. Operational information from outer space as a whole will increase the reliability of the forecast of earthquakes and volcanic eruptions, tornadoes and tsunamis, landslides and mudflows, submergence and flooding, as well as other hazardous geological processes on the Earth.

Kutas R.I., Tsvyashchenko V.A., Korchagin I.N. (1989). Modeling the thermal field of the continental lithosphere. Kiev: Naukova Dumka, 192 p. (in Russian).

Lyalko V.I. (1985). Heat-mass transfer in the lithosphere. Kiev: Naukova Dumka, 260 p. (in Russian).

Morozova L.I. (1980). Manifestation of the Main Ural Faultinthecloudyfieldonthe satellite images. Issledovanie Zemlii z kosmosa, № 3, p. 101-103 (in Russian).

Morozova L.I. (1993). Cloudy indicators for geodynamics of the earth's crust. Izvestiya AN SSSR, Fizika Zemli, No 10, p. 108-112 (in Russian). 
Morozova L.I. (1996). Features of the manifestation of litho-atmospheric relations during the periods of strong earthquakes in Asia. Izvestiya RAN, Fizika Zemli, No 5, p. 63 -68 (in Russian).

Mushketov I.V., Mushketov D.I. (1935). Physicalgeology. Moscow, Leningrad: ONTI, 908 p. (in Russian).

Shestopalov V.M., Lukin A.E., Zgonnik V.A., Makarenko V.N., Larin N.V., Bohuslavsky A.S. (2018). Essays on the degassing of the Earth. Kiev, 632 p. (in Russian).

\section{Список літератури}

Бондарчук В.Г. Основные вопросы тектоорогении. Киев: Изд-во АН УССР, 1961. 381 с.

Бондур В.Г., Зверев А.Т., Гапонова Е.В. Предвестниковая изменчивость линеаментных систем, выявляемых по космическим изображениям, в период сильных землетрясений. Исследование Земли из космоса. 2016. № 3. С. 3-12.

Вернадський B.I. Вибрані праці. Киев: Наук. думка, 2005. $303 \mathrm{c}$.

Воробйов А.І., Лялько В.І., Мельниченко Т.А., Подорван В.M. Прояви аномалій хмарності на супутникових зображеннях перед сильними землетрусами. Укр. журн. дистан. зондування Землі. 2016. № 10. C. 21-25.

Кутас Р.И., Цвященко В.А., Корчагин И.Н. Моделирование теплового поля континентальной литосферы. Киев: Наук. думка, 1989. 192 с.

Лялько В.И. Тепломассоперенос в литосфере. Киев: Наук. думка, 1985. 260 с.

Морозова Л. И. Проявление Главного Уральского разлома в поле облачности на космических
Shou Z. (2006). Precursor of the largest earthquake of the last forty years. New Concepts in Global Tectonics Newsletter, No. 41, p. 6-15 (in English).

Vernadsky V.I., (2005). Featured Works. Kiev: Naukova Dumka, 330 p. (in Ukrainian).

Vorobyov A.I., Lyalko V.I., Melnichenko T.A., Podorvan V.M. (2016) Manifestations of the cloudiness anomalies on the satellite images before strong earthquakes. Ukrainskiy zhurnal dystantsiynogo zonduvannya Zemli, No. 10, p. 21-25 (in Ukrainian).

снимках. Исследование Земли из космоса. 1980. № 3. C. 101-103.

Морозова Л.И. Облачные индикаторы геодинамики земной коры. Изв. АН СССР. Физика Земли. 1993. № 10. C. 108-112.

Морозова Л.И. Особенности проявления лито-атмосферных связей в периоды сильных землетрясений Азии. Изв. РАН. Физика Земли. 1996. № 5. С. 63-68.

Мушкетов И.В., Мушкетов Д.И. Физическая геология. Москва; Ленинград: ОНТИ, 1935. 908 с.

Чебаненко И.И. Теоретические аспекты тектонической делимости земной коры. Киев: Наук. думка, 1977. 83 с.

Шестопалов В.М., Лукин А.Е., Згонник В.А., Макаренко В.Н., Ларин Н.В., Богуславский А.С. Очерки дегазации Земли. Киев, 2018. 632 с.

Shou $Z$. Precursor of the largest earthquake of the last forty years. New Concepts in Global Tectonics Newsletter. 2006. No. 41. P. 6-15.

Received

February 11, 2019 